\title{
Restructuring and National Security for Socio-Economic Development in Nigeria
}

\author{
Davis Efeurhobo \& Christmas Fredrick \\ http://dx.doi./org/10.4314/ujah.v21i3.7
}

\begin{abstract}
The paper examined Restructuring and National Security to ascertain how this could possibly enhance and sustain a better nation amidst the many crises that have endangered the unity of our peaceful coexistence. It is imperative to acknowledge that the unending squabbles and schisms threatening the peaceful coexistence of the Nigerian-state is traceable to improper restructuring of the political system. The paper which relied on secondary sources of data submits that addressing issues of ineffective representation, non-inclusion of persons of different segments, religious intolerance among others would help to promote National Security. The paper therefore argues that issues that are capable of triggering crisis and destroying the National Security, should be tackled adequately in order to have an orderly society devoid of rancour and endless acrimony. The conclusion of the paper was anchored on genuine restructuring with proper recommendations that would help promote an organized and egalitarian society.
\end{abstract}

Keywords: Restructuring, National Security, Peaceful Co-existence, Development

\section{Introduction}

The quest for restructuring in the Nigerian polity has become a serious academic discourse in contemporary time because of the agitations and arguments arising from denials of the national cake by certain powerful forces and ethnic schism in a country that is 
supposedly owned by all. These agitations and quests arose from the structural imbalance of the federating unit. For some intellectual pundits and policy analysts, the unending quagmire threatening the peaceful coexistence of the country emanated from a political system that is highly tailored towards some sections of the country at the expense of other ethnic nationalities. This situation has generated a lot of confusion, distrust and disagreements among all that have agreed to live together under a federal arrangement. It is common knowledge that one of the reasons for adopting federalism is to put the fear of the minority to rest. That is for fear of conquest by external aggression but, today in Nigeria, the reverse is the case as the minority ethnic nationalities are gradually being swallowed by the actions and activities of the major ethnic groups arising from the conspicuous struggle to gain ascendency over other smaller groups. Thus, the imbalance in the structural arrangements virtually in some key sectors of the national economy has been keenly and clearly identified by some intellectual pundits, policy makers, opinion leaders and other relevant stakeholders as the causal factor. This imbalance has consequently led to violent agitation across the nation. The idea is to give a fair treatment to all in order to promote a healthy and egalitarian society where peace and oneness prevails. Hence, the desire for restructuring that will enhance and promote security in our national development where peaceful co-existence and socioeconomic development is inevitable. This is because some notable areas of imbalance in the federation gave room for this agitation and violent conflict that threatens the peaceful co-existence of the sovereign state at the moment. Some of these areas are leadership, employment status, appointments into key positions of governance, among others.

The aforementioned have generated controversies and disagreements that have made some sections of the federating unit to feel marginalized and poorly treated. For instance, the leadership of 
this country seems to be tilted to the North even though some of the Northern Oligarchs argued some time ago that it was their birth right to lead the country. These self-imposed beliefs have been the guiding principles by the North till date which more often than not has adversely affected our national unity in almost all ramifications. Very recently, the controversy over "RUGA" (that is the settlement of Fulani Herdsmen and their flock) in different parts of the country has been an issue in the political domain. In a federal state like Nigeria, this imposition by a section of the country should not arise not to talk of its implementation, as it is capable of instigating crisis that may consistently result in political instability.

Perhaps, it is this awkward behaviour of most Nigerians that reflects in our different places of national assignment that prompted the late NAFDAC boss Dora Akunyili to come up with the policy of rebranding Nigeria. Although, it generated some controversies among the intellectual pundits, policy makers, students and opinion leaders' as it is difficult to change a full grown adult from his old, archaic and mundane ways of pursing personal interest and national goals of development. In contemporary Nigeria, what has dominated the political terrain is restructuring for a better and more habitable Nigeria that will serve as germane and propelling force for national growth and development. Alapiki (2017), looks at restructuring as a process of acquiring a fundamental internal change that alters the relationship between different components or elements of organization or internal change that alters the relationship between different components or elements of organization. The persistent and consistent agitations of Nigerians over the structural imbalance of the federation call for the restructuring of this magnitude. The centre can no longer hold as things are falling apart on daily basis because of the overwhelming and parochial approach to the national resources by a collective few. In the political development, as noted by Udah (2018), Nigeria should be restructured to meet the dictates of true federalism, 
where political and economic structures are in tandem with the overall interests and overall well-being of all the segments or ethnic nationalities that constitute the Federal Republic of Nigeria.

It is in this light that Nnamdi Kanu, the crusader for the indigenous people of Biafra should be commended and widely acknowledged. He pursued this struggle with every vigour some three years ago until he was chased out of the country by the opposition of restructuring. Even till date he has not relented, despite his sudden disappearance. It is pertinent to note that the calls for rebranding and restructuring reveal without any equanimity that something is fundamentally wrong with our sovereign national state. The agitations and struggles by some patriotic elements of this country towards the actualization of restructuring is a concomitant nexus for political stability that will help promote and sustain national cohesion as a means to conveniently meet the needs and expectations of the average Nigeria. This paper therefore takes a cursory look at restructuring and national security in Nigeria, how it can enhance peaceful co-existence and socio-economic development.

\section{Conceptual Clarifications \\ Restructuring}

The term restructuring implies refinement, transformation, changes that will bring about some levels of justice and development in a given polity that is structurally imbalance politically. The unending agitations over resource distribution and other socio-economic and key political appointment in the federation among others created room for this concept in Nigeria. Flowing from some of the perspectives posited by different shades of Nigerian leaders as compiled by Aziken, et al (2017) and Abah, (2017), "the following should be noted; According to General Ibrahim Babangida, while the unity of the nation is not negotiable, structures should be strengthened to make the union more functional based on the state comparative 
advantages". Restructuring implies change, and change denotes a departure from the old order to a new one. Restructuring can therefore mean fundamental change in the building block of a nation's educational system: change in the social, economic, infrastructure and political landscape of a nation. (Ibok, Owouko \& Out,Sunday, 2018). According to Atiku (2017), it means effecting changes to the current federal structure to bring closer to what the founding leaders erected in order to address the very issues and challenges that led them to opt for a less centralized system.

\section{National Security}

National security connotes internal peace and order. It encompasses orderliness, protection of lives and property are guaranteed through security apparatus. In this case, people are expected to go about their normal and legitimate businesses without fear or threat of fear. National security is a situation of defence or protection of lives and property of a country against attack or invasion by external enemies or defence against criminal activities within the country triggered by deprivation-, poverty, hunger and other socio-political and religious factors through security agencies. It is also a state of feeling safe from danger or worry (Horny, 2010). Imobighe (1990) describes national security as freedom from danger, or from threats to a nation's ability to protect and defend itself, promote its cherished values and legitimate interests, and enhance the wellbeing of its people. Enahoro (2004) elaborates further when he said that national security entails a condition in which citizens of a country enjoy a free peaceful, and safe environment and have access to resources which will enable them to enjoy the basic necessities of life.

\section{Peaceful Co-existence}

Peaceful coexistence is a situation of order anchored on the harmonious relationship that exists between and among people 
occupying a particular area. It is a living condition that is sustained by peace, happiness and other traits that enhance good and quality living. There is peaceful coexistence, if members of the same community live together with little or no rancour in pursuit of human endeavour.

\section{Development}

The term development generally connotes the socio-economic upliftment of a people within a specified period of time. It is the process of economic and political transformation that reflects on the attitude and ways of life of a people. Okowa (1996) sees it to mean hardwork, discipline, commitment, skills and the intelligent utilization of the faculty of man in a sustained manner over a fairly long period of time. Development can equally be seen as a type of social change in which new ideas are introduced into a social system in order to produce higher per capital income and levels of living through more modern production in methods and improved social organization, (Obi 2006). It is development when the sovereign state is able to provide for her citizens economically with all the attendant values of human existence. Supporting the above, Todaro and Smith (2004) perceived development as the capacity to move the society away from a condition of life widely perceived as unsatisfactory towards a condition of life regarded as materially and spiritually better. Put succinctly, it is the process by which people create and recreate themselves and their life circumstances to realize higher levels of civilization in accordance with their own choices and values (Ake, 2001).

\section{Restructuring and National Security for Socio-economic Development in Nigeria}

The cry for the restructuring of our national polity has attracted comments from intellectual pundits, opinion leaders, scholars and students, to mention a few. This is because national security is 
threatened by the different agitations, rancour and violence orchestrated by the structural imbalance of the federating units. Nigeria that operates under the guise of federation seems to be unstable politically and economically because of the degree of prejudice in the distribution of the national cake. Therefore, violence, disagreements, unending agitations in recent time have started threatening the peaceful co-existence of the sovereign state. National security that is built on a sound foundation of justice, equity and fairplay is threatened because of the imbalance in different strata of the society and so, many patriotic and law abiding citizens of the country having taken pains and time to examine the cause of these agitations found out without equanimity the need to restructure the country in order to give peace a chance.

The development of any nation hinges on the social and economic contributions of her citizens. Educational, vocational and technical training play a major role at promoting community and national development (Oguntuyi, 2013). The restructuring of a country can only guarantee this because the beauty of restructuring fosters peaceful living, cooperation and collaboration in the use of resources independently towards the national integration of a country. But, this pursuit of national endeavour is stifled and mitigated because of the overwhelming and domineering attitude sectors of the federation, championed by some ethnic and religious bigots to illegally acquire wealth to themselves through the structural imbalance deliberately and consciously design to suit their whims and caprices. This is at the expense of others in a federating state that is supposedly owned by all. Akpomie (2009) asserts that no nation can move forward technologically, industrially and economically without developing a strong partner initiative in the creation of wealth, poverty reduction and employment generation with required skills. Corroborating this, Sekoni (2017), acknowledged that "the concept has value by promoting and safeguarding a sense of belonging among 
various components of socially and culturally plural society through the creation of practices that set out to advance social and economic interests of members of the community or society. Restructuring, therefore in the words of Ossamor (2018) is a clarion call for the furtherance of socio-economic advancement for any nation irrespective of other factors which may be deterrent to such advancement. It is a matter of fact, the only remedy to removing existing practices that may be perceived as negative to the interest of federating units and adding new practices that can enrich such interests.

\section{Restructuring and National Security}

Restructuring implies a genuine process of correcting the structural imbalance of the federating units that are capable of triggering crisis. National security on the other hand promotes orderliness and justice through the instrumentalities of government institutions and structures. The police, the army, legislature, National Orientation Agency (NOA), Independent National Electoral Commission (INEC), executive, judiciary, among others are examples of institutions and structures that are capable of promoting peace and tranquillity in every federating state through national security. An institution must reflect the feasibility and desirability of the people who participate in it (Asike, 2017). Unfortunately, the agitations, violence and disagreements among Nigerians are caused by poor and selfish management of the national resources arising from structural imbalance tilted to suit the whims and caprices of the leadership that often time threatened the inhabitants as some of the aforementioned institutions and structures are used to distribute the national resources with little or no consideration for the other disadvantaged minority class. This has recently charged the atmosphere with a lot of protest, "hate speeches" "quite order" and such other inciting statements from different political divide of the country. Nwoko (2016) observed that 
lack of clear delineation of intergovernmental roles is a major obstacle to progress. Some level of interaction across the federating units guarantees peaceful and harmonious living. Besides, national security will help to enhance and sustained social justice. Social justice is a principle that requires society to maintain some minimum conditions of living for all its members. It emphasizes just and fair distribution of social goods and services such as housing, education, food, portable water, healthcare facilities and so on to ensure the survival of individuals while making them live the good life (Uyanga, 2014). Consequently, this will enhance continuous and aggressive investment in human capacity development and provision for quality life. More importantly, it will enhance and sustain some level of stability and cohesion when existing federal component units are at peace with one another without litigations and antagonism. Development, national integration among others that constitute the beauty of a federal state is achievable. The growth of any nation is bound to its ability to maintain peace, foster unity, eradicate poverty and build on the successes of each developmental phase of the country (Shaljaba, 2019). When this is done in a highly competitive federal state such as ours, security is guaranteed and development is sure. According to Shaljaba (2019), "development is security and security is development; when you don't develop, you will experience insecurity, and when you have insecurity, you cannot develop. The logical derivation of this pronouncement is that the absence of security is orchestrated by the internal wrangling and absence of development, which has become a nauseating issue in our country today. The level of national integration and nationhood is nothing to write home about. Over 50 years of political independence, we still see ourselves as different people, we vote based on ethnicity or religion, among others (Shaljaba, 2019). 


\section{Restructuring and Socio-Economic Development in Nigeria}

The agitation for restructuring as a result of the structural imbalance of the federation by persons, scholars who have conspicuously seen the damage it has done to some sections of the country will help to improve on the socio-economic development of Nigeria. This is because it will give deserving autonomy and will for all the existing federating units to independently without prejudice contribute their quota to development of the country as a whole rather than dissipating their energies on arguments over the lop-sidedness of the federating units. The fact that some sections of the country are in the hands of a privilege few speaks volume on the lop-sidedness of the poor political arrangement. The Christian and Islamic religious ethos and pathos that were supposed to be the guiding principles are tearing the people apart. This is simply because of accusations and allegations of neglect, oppression, domination, exploitation, victimization, discrimination, marginalization, nepotism and bigotry" (Asike, 2017).

Consequently, this unpleasant development has had adverse effects and implications on socio-economic development in Nigeria, as people of different religions no longer trust themselves even in their trade relationship. Invariably, social justice suffers. In the words of Aminigo and Nnaokugha (2011) "social justice demands that the state and its leaders put in place social mechanisms through which the poor masses can realize their potentials without much difficulty. Social justice is an idea of supporting individuals within collective units of social existence". All these are possible through effective and efficient restructuring of an imbalance federation such as ours. When this is achieved, socio-economic development is guaranteed.

Unfortunately, the poor political arrangements has killed the patriotic zeal and desire towards actualizing the national goal as most leaders who are privilege to assess the national cake seems to be more concern about their areas than the country as a whole. Thus, forces such as ethnicity religion, politics and such other variables becomes 
the determining factor in sharing the national cake. These aforementioned variables conspicuously come into glare during elections as the basis for electing leaders is centred on ethnicity as well as religion. Consequently, socio-economic activities suffer adversely in areas where the leader(s) did not emerge from. Thus, it is not incorrect if one alleges that the Nigeria federation is operating a unitary system of government. This is because all the component units seem to be playing a subordinate rule rather than being independent in their constitutional responsibilities and functions. On the other hand, scholars like Akpotor (2007) argued from their own perspective that federalism is essentially a bargaining process. According to him, the factors that account for the emergence of the federal states are not to be found in a legal document, but rather in the factors that propels the leaders of various groups to enter into bargaining process, to form a union. There is thus, a total deviation from the practice and principles that sustain a true federal state. Ethnicity, particularly seems to be playing a negative role in this unpleasant arrangement towards the sharing of what ordinarily should belong to all that have agreed peace fully to form the union of convenience. According to Njoku (2007), the problem of inter-ethnic conflicts arises from unhealthy inter-ethnic competition for scarce resources, sustained inter-ethnic suspicion and hatred emanating from the past hostile inter-group relations and the manipulations of vicious political leaders, all tend to pose serious threat to inter-ethnic harmony and stable internal security of the country. He further reiterated that the growing incidence of ethnic nationalism and tribal parochialism tend to ignite social insecurity in some parts when the federal system actually kicked off the different regions (North, South and East) operated with the greatest of ease and autonomy in the efficient distribution of the resources meant for the regions. More importantly, the individual contribution of these region was for the overall interest of the national government. 
Politics of ethnicity and religion have seriously undermined this progressive gesture. Consequently, the relative peace and political stability is threatened. Ball and Dagger (1995) acknowledge that; Nigeria's heterogeneous character is evident in the diversity of its ethnic and religious groups. These diversities have often constituted a source of conflict within the entity. Perhaps, cognizance of the fact religion represents a political force capable of pushing in different directions. (P.253). The overwhelming implications of this sad development is the unending squabbles borne of out of very serious competition to pursue socio-economic activities. Often time, this competition fuels the ember of disunity and anger among these who should have seen themselves as one despite the variables of religion and ethnicity that seem to be heating the polity at the moment. The further implication of this poor arrangement is that peaceful coexistence is being threatened almost on daily basis. According 'to Asike (2017), the basic social change process of the transformation has turned to conflict as it provokes fear about the loss of a society's identity religious identity, and stimulates resistance and rediscovery or invention of indigenous tradition.

\section{Conclusion}

Peaceful co-existence which is anchored on socio-economic development can only be possible to a very large extent when the country is properly restructured. It is this restructuring that will help to enhance and sustain national security. The seeming agitations and hullabaloo that have taken grip of the nation today, are as a result of the senseless and reckless acquisition of wealth by some ethnic and religious bigots, who by hook or crook means have had access to the means of power, and have decided to use it for their own interest at the expense of the generality of the country, who have been made to suffer the many effects of a structurally imbalance federal arrangements. According to Oganwu and Babtunde (2018), the 
hundreds of millions of people who are not currently enfranchised by the economic and political system want in, not out. They see the world on the move and full of opportunity, innovation and prosperity, and this defines their expectations. They simply want their states economies and societies to function. But their daily encounters with the state produce frustration and humiliation. They know that it is the dysfunctional state that stands between them and a better life. Corroborating the above, Asike (2017) has this to say, as Nigerians prepared for independence, in 1960, they had no alternatives than to resort to their faith in the union of a nation state. They felt the need to merge, irrespective of their ethnic, religious, cultural and political differences. Constitutionally, they agreed to live together as a nation, but still have not been committed to build the nation. When the state is generally perceived as serving the partner interest of one group, it starts losing its legitimacy and indeed its authority. As capacity declines, fear of uncertainty increases to an extent that citizen's resort to other levels of solidarity viz religious, ethnic, regional and so on, with a view of getting guaranteed security. This is the situation the poor political arrangement in the name of federalism has landed this nation. The security apparatus has been overstretched with the attendant of effect of human lives being lost on daily basis as a result of competition that is anchored on ethnic political and religious variables.

\section{Recommendations}

In order to possibly position Nigeria to achieve peaceful co-existence and socio-economic development, the following recommendations were considered in the light of this quagmire.

1. Ethnicity should be completely disregarded in our national politics. This is because ethnicity has polarized this country in many ways than one, 
2. National resources that is collectively owned should be equitably and justly distributed.

3. Issues and problems that have threatened the peaceful coexistence of the sovereign state should be sincerely and adequately addressed.

4. The application of the rule of law should be total. It is the absence of it that galvanize the need for restructuring where some persons feel they are above the law.

5. Leadership should not be seen as the birth right of any segment of the federation that has agreed to form the entity called Nigeria.

6. Promoters of "hate speeches", "quit order" among others that are capable of triggering division in the country should be called to order.

7. The practice of true federalism should be encouraged. This can only be possible with proper restructuring of the country. It will enhance autonomy and promote synergy in the development of all the federating units.

Davis Efeurhobo, PhD

Department of Political Science

College of Education, Agbor

Delta State, Nigeria

ochukodavis2019@gmail.com

\&

\section{Christmas Fredrick}

Department of Political Science

College of Education, Agbor

Delta State, Nigeria 


\section{References}

Abah, H. Ibrahim, Y. Echozie, V. (2017). July 9, 10 Nigerian leaders, 10 ideas about restructuring. Daily Trust Newspapers.

Ake, C. (2001), Democracy and development in Africa: Ibadan: Spectrum Books limited.

Akpomie, M.E. (2009). Achieving millennium development goals (MDGs) through teaching entrepreneurship education in Nigeria higher education institution (HELs), Eur. Journal science, 8 (1), 154-157.

Akpotor, S. and Oromareghake, P. (2007). Federalism; Case Studies and Comparative Federalism. Benin City. Allen Publications.

Alapiki, .H. (2017). Oil and Democracy in Nigeria: A Paper Presented at $25^{\text {th }}$ Annual Conference of Nigeria. Political Science Association (NISA) University of Port-Harcourt, Nigeria.

Asike, J. and Anwuluorah, P. (2017). Social change and the crises of religious politics in Nigeria. Onitsha; St Stephen's Printing press.

Atiku, A. (2017). Restructuring Nigeria for national cohesion and good governance. Vanguard July, 6.

Aziken E. Ndiyile, C. Akinrefon, D. and kumolu, C. (2017, June 13). Nigeria. What is restructuring? Vanguard.

Ball, T. \& Dagger, R. (1995). Political ideologies and democratic ideals. New York: Harper Collins College.

Enahoro, D.O. (2004). Path to understanding military strategy. A lecture delivered at the National War College, Abuja Nigeria, to participants of course 13 (20 October, 2004).

Hornby, A.S. (2010). Oxford advanced learner's dictionary of current English. Oxford University Press.

Ibok, O. and Otu, S. (2018). Restructuring Nigeria through educational administration: the role of sustainable educational policy in; Niger Delta journal of education vol. 4 No.2, August, 2018.

Imobighe, .T. (2003). Nigerians defence and national security linkages. Ibadan. Heineman Educational Book Nigerian Plc.

Nwoko, C. (2015). Financing education in Nigeria opportunities for action: education for development country case study for the 
Oslo summit on Education for development. Edu summit Oslo education for development. 6-7 July. Available at htt:// relief web. Int/sites/relief web. Int/files/resources/Nigeria nett.pdf.

Obi, A. (2006). Development administration: Onitsha Book Pomt Ltd.

Oganwu, P. \& Babtunde, W. (2018). Social studies education: agent of change in Nigeria's socio-political history; In Niger Delta Journal of Education. Vol. 4, No.2.

Oguntuyi, A.N. (2013). A viable vocational technical education curriculum: a tool for economic and technological development in Nigeria, Scholarly Journal of Education, 2 (2), 22-26.

Okowa, W.J. (1996). How the tropics underdeveloped the negores. PortHarcourt Paragraphic Publishers.

Osammor, U. (2018). Restructuring theatre arts education for sustainable development. In; Niger Delta journal of education vol. 4 No.2 August 2018.

Shaljaba, D. (2019). Restructuring only solution to development. Vanguard, Tuesday August 6, p.42.

Sekoni, Ropo. (2017). Restructuring and national unity? www-the nationline.net.13 August.

Todaro, M. \& Smith, S. (2004). Economic development: New Delhi: Pearson Education.

Todaro, M. \& Smith, S. (2004). Economic development: New Delhi: Pearson Education.

Udah, C.S. (2012). Oil, poverty and insecurity in Nigerian international conference on the Nigerian state. Oil Industry and the Niger Delta, Conference Proceeding.

Uyanga, U.D. (2014). Social justice and good governance in Nigeria: implications for education. An unpublished doctoral dissertation submitted to the department of educational foundations, University of Port-Harcourt 